\title{
The Influence of "Art Teaching Guide" on the Concept of Art Education, Teaching Practice and Art Teacher Education in China
}

\author{
Hui Li \\ Nanya Xiangjiang Middle School of Changsha, Changsha 414300, Hunan, China \\ Email: 1490342755@qq.com
}

\begin{abstract}
In China, with the rapid economic development and the general improvement of people's quality, the traditional mode of art education has been unable to meet the needs of social development. The outline of the 14th Five-Year Plan calls for building a high-quality education system and promoting the modernization of education. In the process of vigorously promoting the new curriculum reform, with the overall educational goal of cultivating students' "core qualities" and promoting people's all-round development, China has introduced advanced western educational concepts in the aspect of fine arts education and adopted corresponding measures to reform China's fine arts education. This article discusses the influence of "Art Teaching Guide" written by American professors Mike Parks and John Cesca on Chinese art education philosophy, teaching practice and art teacher education. Finally, combining with the actual situation of Chinese art education, the author expresses some thoughts and hopes about the content of this book.

Keywords: art education, art teacher education, creative teaching
\end{abstract}

\section{The background of Chinese contemporary art education}

China in the 21 st century, with the development of the economy and the improvement of the quality of the people, basic art education is increasingly demonstrating its significance and endless charm. However, in the context of the era of globalization and multi-context, the society's demand for talents is changing with each passing day, and higher requirements and goals are also set for art education. In response to various complex problems in society, "education should cultivate people's ability to solve practical problems", which is fundamentally derived from Dewey's pragmatic philosophical foundation, has once again attracted widespread attention and attention. In the course of vigorously promoting education reform in China, the "core literacy" entered the Chinese curriculum in 2015, and the Ministry of education of the people's Republic of China officially announced the art curriculum standard for senior high schools (2017 Edition) in 2018, marking that China's basic art education began to be officially transferred to the implementation of core literacy. ${ }^{[1]}$

\section{The main content of "Art Teaching Guide" and its influence on Chinese art education}

The publishing house of "Art Teaching Guide" is Pearson Education (US), and the authors are Professor Mike Parkes and Professor John Ceska from the United States. The selection of this series is the current bibliography for graduate students majoring in art education at Columbia University. This book can be described as a window to understand the concepts and methods of contemporary American art education. In addition, the book is based on the basic concepts of art literacy, citing views and writings from curriculum experts, educational psychologists, behavioral scientists, brain research experts and other fields, combined with cases or operating guides, to provide guiding help for Chinese art educators to formulate a new art curriculum in terms of methods, knowledge and motivation, which is of great significance to the rapid development of art education in China. Specifically, there are mainly the following points:

\subsection{From the perspective of the essence of art and human development, the art education focusing} on skills and knowledge is returned to its nature and characteristics

Visual art occupies an important position in human history which is a way to perceive, understand, communicate and respond to the world. This book starts from the influence of art on art education, and analyzes the influence of art education by modernism. Most of them are not moving forward. The main purpose of the course is to understand the characteristics of form. This situation has nothing to do with the remarkable ideas of contemporary art and culture under the background of postmodernism. Looking back at our internal and external art classes, including students, are more like skill training classes under a single mode, ignoring the humanistic and ideological characteristics of art. The author holds the belief that art is 
closely related to thought and believes that art education needs to return to the essence of art.Through understanding art, students can achieve a higher level of orderly thinking goal in education, and this goal is derived from art quality. Therefore, the author puts forward the standards that fine arts need to establish connections with life, social needs and other disciplines. Art understanding includes background, content and form. The process by which students understand art has cultivated insight, critical ability and creative thinking. This way of thinking can also be applied to other disciplines. This is in line with the core concept of interdisciplinary teaching advocated in the reform of basic education in China.

In China, score theory plays a dominant role in student evaluation. In this environment, it is easy for primary and middle school students to lose the opportunity and motivation of thinking, followed by the gradual increase of students' psychological and moral problems. Mr. Cai Yuanpei, a great educator in modern China, once mentioned the purpose of "complete its morality with aesthetic education". Art education has a good combination of aesthetic, emotional and thinking skills. Through art education to beautify the mind, students understand art, and use the window of art to understand the world and see their position clearly. This has positive significance for helping students establish a good outlook on life and values and world early in basic education, and has laid the foundation stone for them to solve broader life problems in their lifelong development. Therefore, this book presents the direction and approach of the modernization of art education in terms of the nature and characteristics, functions and effects of art education, and has a foundational effect on the study of art curriculum around "core literacy" in China.

\section{2 "Art Teaching Guide" explores the innovative ideas of understanding art teaching methods ${ }^{[2]}$}

For a long time, Chinese educational thought has been influenced by subject-centrism, and the model art curriculum and teaching have gradually lost the charm of the subject, and has accumulated many problems, such as: classroom content is limited to textbooks and stylized Teaching links, instillation-style teaching mode, fancy activities but free from simple knowledge learning, chaotic procedures and forgetting the teaching goals, students lack creativity and vitality, etc. In order to form a high-level thinking exploratory art classroom, this book explores specific and effective teaching methods and approaches with the latest ideas in the art field, and focuses on the systematic interpretation of art courses and teaching methods, which is specifically embodied in the following. (1) Based on the essence of art, The basic concept of art class should start with the theme. The book expounds how to find some theme ideas in art, and discusses the design of learning activities, that is, examples of assessment homework, so as to help students explore through high-level thinking. In addition, teachers are provided with multiple evaluation methods to judge whether students really understand a certain concept. (2) Teaching organization: In order to ensure that students can learn real skills in the classroom, the author clarified the importance of teaching process and focused on daily teaching procedures. Using Madera Hunt's "Basic Elements of Teaching" as an example, he interpreted the elements of expectation setting, classroom goals, knowledge information, teaching mode, assessment strategies, in-class exercises, independent exercises, and end activities. (3) Focusing on constructing classrooms and driving students to meaningful discussions, corresponding requirements and guidance are put forward for classroom management, art materials, teaching aids, templates, etc. (4) In the era of visual culture, this book advocates innovative concepts, transcends the scope of the classroom, promotes art discussion and writing, and explores some implementation ways and methods for art history, aesthetics and art criticism to enter the art classroom, so that students have visual literacy and produce art deep and lasting understanding. The exploration of the above courses and teaching methods challenged the traditional art teaching model, established the overall framework of the new curriculum, and provided a guide for China's art curriculum reform with the cultivation of student literacy as the core.

\subsection{It is of great significance to the growth and training of Chinese teachers}

The foothold of art education reform lies in the curriculum, and the mission of curriculum and teaching ultimately falls on the shoulders of art teachers.[3] The art teacher team in China's primary and middle schools is composed of normal art students and art majors. Art majors are required to pass the corresponding teacher qualification examinations for education. The content of the examinations includes pedagogy and educational psychology, as well as short academic trial teaching. After obtaining the certificate, students can apply for teacher positions. Among the group of art teachers, art majors account for no less than normal students. However, due to the lack of systematic normal education and no pre job practice, such new teachers have no way to start teaching, including difficulties in transforming art practice into teaching, unable to teach, not understanding students, not familiar with curriculum standards and so on. In fact, to become an excellent art teacher, time accumulation is far from enough. The teacher training guide in the "Art Teaching Guide" bridges this loophole. At the same time, its broad vision and philosophy are very meaningful for the current professional development of teachers.

It is mentioned in the book that art teachers must have a broader global vision and master the latest views than before, not only because of the complexity of contemporary art education, but also because today's art teachers need to play a more 
active role in a wider campus group. Specifically, teachers must have a deep understanding of the operation of thinking and the way information is processed in order to avoid teaching short and narrow art knowledge to ensure the complex ideological discipline of art. Therefore, the book provides a large overview of the three major learning areas of Bloom and others, helping teachers to master thinking skills and thinking tendencies to cultivate students' higher-order thinking skills. And the author extensively presented Piaget and Vygotsky's cognitive development theory, Ronfeld's theory of creativity and psychological growth, the brain subject theory, Gardner's theory of multiple intelligences, etc, helping teachers understand the development of students' mind and ability from multiple perspectives, so as to tap students' maximum potential. Finally, the end of the book gives standards and requirements on teachers' responsibilities and accomplishments, and provides some practical and feasible methods for teachers to realize their educational ideals. Therefore, this book has a new beacon for the current Chinese teacher education reform, and has poured new wisdom into China's art education.

\section{Thoughts based on the background of Chinese art education}

In the process of Chinese education learning from the West, Mr. Kang Youwei, a modern thinker and educator, once put forward "the magic of combining Chinese and Western". After reading this book, based on the current art education environment in China, the author has a few thoughts.

\subsection{Pay attention to the customs and cultural background of local students}

China is a country of multi-regional and multi-ethnic cultural integration. Students from different regions may represent different customs and cultures. The cultural diversity also presents a splendid folk art culture. Therefore, in the art education research of the new curriculum standard and the new curriculum reform, the students' cultural and social background should be respected, and flexible and targeted art education should be implemented. For example, based on the essence of art and advanced educational concepts, the research and development of folk art curriculum resources and the research of educational goals and so on.

\subsection{Domestic art education combines Western art and "brush" style Chinese painting, and implements a dual-track art teaching system}

Chinese painting has a long history in China and occupies a dominant position in Chinese art. In the teaching of Chinese painting or calligraphy in primary and secondary schools, how to ingeniously combine the principles of Western art education, this angle also triggered my thinking.

\subsection{How to popularize advanced art education concepts in every classroom}

The final "foothold" of the implementation of art education is in the classroom. Chinese art education in the 21 st century has undergone several important changes, and its purpose and philosophy have also undergone fundamental changes in keeping with the times. However, as mentioned in the article, Chinese art education still tends to impart knowledge, skills and formal characteristics, which is difficult to achieve the educational goal of cultivating students' "core literacy of art".The "Art Teaching Guide" provides some effective strategies in terms of the nature and characteristics of art education, curriculum and teaching, teacher training, etc. It has certain significance for China to implement and popularize new art education concepts. However, this book does not talk about how to connect the gap between educational decision-making and policy and the implementation of art teaching. This issue requires the joint efforts of art education reformers and implementers. At the same time, I also hope that the author can provide some relevant content on how to link the art education policy and popularize the education and teaching methods in the United States.

\section{References}

[1] Yin Shaochun. Everybody's Opinion of the Core Literacy of Fine Arts[M]. Changsha: Hunan Fine Arts Publishing House. 2018: 3.

[2] Ji Yuesheng. Analysis of Teaching Methods of Fine Arts Education Curriculum -- Comment on Exploration of Fine Arts Education Curriculum and Teaching Methods[J]. Research in Educational Development. 2021; (11): 41.

[3] Qian Chuxi. The Innovation of Fine Arts Teacher Education Connected with Art Courses of Primary and Secondary School[J]. Research of Modern Basic Education. 2015; (18): 28-33. 